\title{
THE EFFECT OF LEARNER DIFFERENCES AND TEACHING OF COLLOCATION ON STUDENTS' COLLOCATION COMPETENCE
}

\author{
Endah Ginanti ${ }^{1)}$, Eko Fachtur Rochman ${ }^{2)}$ \\ STIE Jaya Negara Tamansiswa \\ indahginanti@gmail.com
}

\begin{abstract}
Collocation has a fairly prominent role in English Language. For non-native speakers, the years learning English does not mean non-native speakers are able to apply collocation correctly. Non-native speakers will face great difficulty in collocation because they have limited quantity of doing much exposure and their learner differences such as motivation. This current study critically reviews Mansoor Ganji's (2012) work which investigated the influence of Gender and Years of Instruction on Iranian EFL learners' Collocational Competence. Ganji's found that Iranian English majors were weak in lexical collocation in spite of English had been taught at least 6 years and English teachers were blamed since they seemed not to pay enough attention to collocation teaching in Iran. This study is descriptive quantitative. The results indicates that students of nursing department at STIKES Widya Cipta Husada are also weak in collocation. However, English teachers cannot be blamed on students' weaknesses on collocation because English teachers had taught collocation both implicitly and explicitly.
\end{abstract}

Keywords: learner differences, collocation, students' competence

CPendidikan Bahasa Inggris FPISH IKIP BU Malang

\section{Introduction}

Collocation is a blend of two or more words to form a unity of meaning. If one does mistake when combining collocation, the result is not wrong but it is not appropriate. Prendergast (1864:82) stated that students learn not only just words but also chunks of a language. When students memorized it as complete units, the chunks is seemed to be so well-mastered and students later use it fluently. Native speakers will not make mistake in using collocation since they are familiar and it is used all the time. However, non-native speakers will face great difficulty in using collocation because they do not use collocation all the time. For non-native speakers, the mastery of collocation not only is obtained by a lot of reading and listening but also must do much exposure. For non-native speakers learn collocation, if not accompanied by much doing the exposure, the vain non-native speakers learn collocation. In relation to the importance of collocation, this paper investigates the effect on

learner differences and language learners in producing collocation error.

\section{Ganji's proposal and comments}

The view of Mansoor Ganji's (2012) in his CCS journal article (Vol. 5, Issue 2; February 2012) was used as the main reference. Ganji (2012) conducted a research investigating the influence of Gender and Years of Instruction on Iranian EFL learners' Collocational Competence. His research had three different aims. First, Ganji examined the knowledge of lexical collocations of freshmen, sophomores, and juniors of Iranian university students. Secondly, Ganji was to test whether the years of instruction and participants's gender affected student's lexical collocation knowledge. Third, Ganji was to find out what was the most difficult and easiest collocation for Iranian students. Although Ganji's research focused on those purpose, Ganji's research showed 
that he concerned more on about how many years Iranian EFL had started to learn English and blamed teachers' role which did not pay much attention in teaching collocation. It seems that there are still many factors should be considered before taking to those final result.

To know Iranian EFL learners competence in using collocation, Ganji conducted his research by covering 5 research questions to find out Iranian students' proficient in English lexical collocations, the difference between boys and girls in their knowledge of English lexical collocations, the difference knowledge about English lexical collocations from three different academic levels, and the easiest and most difficult English lexical collocations for Iranian students. Ganji chose Iranian EFL learners because the issues among Iranian EFL learners was that they could not construct a good and natural speech and writing, even though they possessed good grammatical competence. They could get high grades in grammar tests, but regrettably their writing were full of wrong combinations of words (Ganji, 2012). He also added that Iranian EFL collocation' competence was lower than the competence of native speakers.

Ganji used descriptive method in his research. He claimed that his study was the first study in collecting data comprehensively about the collocational competence of Iranian EFL students. The participants were 43 students which twenty-five were males and eighteen were females and age ranged from 18 to 23. Eleven participants were in first year (freshmen), seventeen students were in second year (sophomore), and fifteen students in the third year (junior). Ganji's conducted his research in the English Department of Chabahar Maritime University. All participants were registered in B.A. in Translation
Studies of 2011, a period of 15 weeks. Participants' first language is the official language of Islamic Republic of Iran, Farsi, which is also called Persian.

The instrument used by Ganji was a 50-item fill-in-the-blank of English lexical collocation test which consisted of 5 types of lexical collocations. There were 10 questions for each type of collocation. Five types of collocation used on the test were: verb-noun, adjective-noun, noun-verb, adverb-adjective, and verb-adverb. Ganji employed SPSS version 17, independent sample t-test for comparing the male and female students's performance and oneway ANOVA for comparing students' performances at three academic levels. The finding showed that Iranian university students answered just more than $50 \%$ of the questions. Unfortunately, Ganji does not use treatment in his study. Ganji directly given lexical collocations test to participants.

The result of Ganji's research indicated that Iranian university students were quite weak in lexical collocations in spite of they had studied English for at least 6 years before enrolled the university. Ganji's work seems only as observation at a glance to know students' prior knowledge since there is no clear explanation of what the explicit reasons giving the collocational test directly. He believed that the years students had learned English before entering to the university would increase students' competence in collocation. Ganji stated that Iranian EFL learners did not know what collocation was. It means that Iranian EFL learners never use collocation in their daily life, or if collocation had been taught when they were in Junior High School, if collocation never used by Iranian EFL learners the knowledge of collocation will not be in their long memory term. 
Moreover, there is no feedback when they make errors in using collocation.

Language is a complex phenomenon, moreover for learners who learn foreign language. After students are given input of collocation, it must be reconsidered whether that input is useful or useless. It must be questioned whether there is plenty of time available for language learner to take place, plenty of contact with proficient speakers of the language (Lightbown and Spada, 2001). Thus, it is acceptable if Ganji did treatment such Liu (2000) who gives mini-lessons to her students before giving collocation test to the Iranian EFL learners.

Ganji stated that female students had a lower performance on the collocation test. Boys had better performance in first year and second year. However, female students exceeded boys only in junior class. Ganji's research indicated that there was a significant difference on test of lexical collocations between the freshmen and sophomores. Shopomores students should have a higher level of proficiency than freshmen since they had learned more English. However, freshmen students outperformed sophomores on the lexical collocation test. Iranian university students had highest mean score in collocation type 3 , noun-verb, which was the collocation's easiest type. All the five groups (males, females, freshmen, sophomores, and juniors) and six subgroups (male freshmen, female freshmen, male sophomores, female sophomores, male juniors, and female juniors) correctly answer ten questions. While adverbadjective and verb-adverb were the most difficult types of collocations for fresh females.

Ganji asserted it was quite disappointing knowing students who were involved in Ganji's research were chosen among around one million students who took part in the Iranian National University Entrance Exam annually had weak knowledge in using collocation although the students had studied English at junior and senior high schools for at least 6 years and majoring at English translation study. Unfortunately, Ganji ignored that exposure also has a big role whether the input is successful becomes students long memory term or not.

Next in the research conducted by Ganji, mentioned that collocation did not get enough attention from English teachers. Teachers did not emphasize to give collocational knowledge in their teaching learning processs since teachers were not told to focus on collocation teaching. Unfortunately, Ganji does not complete his statement by giving evidences to strengthen his statement about the content of learning process in Iran, how teachers in Iran teach their students and what kinds of input of linguistic skills were given to students implicitly and explicitly. It is better if Ganji accomplishes his study by showing questionnaire of teaching learning process conducted by teachers to support his arguments.

According to Ganji's research, the easiest type of collocation was VerbNoun form and the most difficult was Adverb-Adjective form. The easiest type of collocation was caused by the mother tongue of Iranian students, and all those collocations had similarity with Farsi. Iranian mother tongue was the facilitating factor which resulted in the performance of Verb-Noun form of collocation. Unfortunately Ganji does not provide questionnaire and observation deeply whether the role of mother tongue carries role in this case. While in case of adverb adjective is the most difficult because Iranian is rarely to use adverb-adjective collocation, it might the factor which affect students' failure in using this type of collocation. A factor can be considered as the reason of students' use inappropriate 
collocation is language learners it selves. In learning language or acquiring language, it is common a learner will make many errors caused by language learners.

Ganji affirmed that Iranian students was seemed to lose their collocational competence as students moved toward later years of study. The reason which Ganji found that freshmen had better proficient than sophomores was most of freshmen had been to English Institutes before coming to university and students dealt with different types of texts and did vocabulary exercises because freshmen had 3 reading courses in the first terms of their studies. However, it is not enough to be judged as a research because it is needed deeply research to investigate the effectiveness of reading courses in the first terms of their studies. When reading courses in the first terms of students studies do not give effects on collocational competence, it should be investigates more whether other factors such as individual differences such as personality, motivation, intelligence, aptitude, learner's belief and learning styles has role in this case. In this study, researcher researchs motivation as the effect of students' collocational competence. And as additional data, researcher adds whether teaching collocation implicitly and explicitly and exposure also have role in students' collocational competence.

Success in learning English is influenced by a variety of variables. One of the variables is the motivation. Gardner and Lambert (1972:148) and Dörnyei (2001:2) states that motivation plays a significant role in achieving SL proficiency and competence. Motivation to learn English as a second language are grouped into several types, they are: integrative motivation and instrumental motivation. One who learns language so that he become part of a community is called integrative motivation. While one who learns languages because they want to achieve their goals such as getting a job, graduating from school or being able to read academic material is instrumental motivation.

Some experts in teaching English as a foreign language also differentiate motivation into two types of motivation (Williams and Burden' 1997), namely intrinsic motivation and external motivation. Many researches show that motivation brings big influence to the language acquisition. Alsayed (2003) in his research 'Factors that contribute to Success in Learning English as Foreign Language' states that motivation (instrumental motivation) has the highest correlation with students' English achievement and early exposure to English seems to be a good predictor for success in oral skills.

According Slameto (1995) smart or high intelligent students are often looked stupid because they do not have the motivation to achieve the best. It means that students who have low motivation will not achieve academic achievement well. Conversely, students who categorized as low intelligent but has high motivation to learn, then he will achieve good academic achievement. According Hamalik (in Djamarah, 2002) motivation is a change in one's personal energy is characterized by the onset of affective (feeling) and the reaction to achieve the goal. In other words, a person has a particular purpose of any activity. Similarly, in the learning process, a person who does not have the motivation to learn, he will not likely do activities and academic performance well. Conversely, someone who has the motivation to learn, he will do better activities and have better academic achievement.

Many studies have shown that students make a lot of mistakes due to lack of exposure to language collocations. Learners who have a habit 
of reading magazine articles, novels and other books, watching movies and listening to English news, makes fewer collocation mistakes than those who do not have the habit. Mother tongue or first language interference is stated to be the cause of another, but this needs to be investigated further. Some people state that English teachers teach individual words but not collocation. This also need further research due to now a day many teachers focus on teaching chunks implicitly or explicitly. There many ways in teaching collocation. Using various activities and media, teachers can increase students' competence in collocation. The important things are teachers should build students' awareness of collocation by teaching individual collocation or by storing collocation.

It has believed that motivation and exposure have the prominent role in acquiring second or foreign language. The years students learn English especially collocation will be useless if they do not do much exposure.

This study is intended to examine the correlation between motivation and collocation's teaching on students' collocational competence as additional supporting data to know the way teachers teach collocation to the students. The research questions are formulated as follows: (1) Is AdverbAdjective the most difficult type of collocation for Nursing department students of STIKes Widya Cipta Husada of Kepanjen?; (2) Does integrative motivation have more influence than instrumental motivation towards Nursing department students of STIKes Widya Cipta Husada of Kepanjen?; (3) What types of teaching collocation have more influence on high achievers and low achievers, teaching collocation implicitly or explicitly?; (4) Do students do much exposure in using collocation to boost their competence?

\section{Research Method}

This study used descriptive quantitative method. Twenty-five students of non-English Department of Stikes Widya Cipta Husada of Kepanjen were involved in this study. They were from Nursing Department who were in the first year of 2018. The students learnt English as foreign language and were taught in form of ESP (English for Specific Purpose). The reason for selecting this university was because the researcher was working in this university as a lecturer.

There were three instruments used in this study. The first instrument was a questionnaire to gain the information about students' motivation in learning English. The second instrument was also a questionnaire to gain information whether students have high motivation or low motivation in learning English. Those type of questionnaires followed Gardner and Lambert (1972:148) motivational measure in Ive Emaliana's research (2003). The first questionnaire consisted of eight questions. The first four statements were for integrative motivation, and the second four statements were for instrumental motivation. The second questionnaire is employed to gain information about students' knowledge of collocation. There are 7 statements in this type of questionnaire.

The third instrument was a 10item multiple choice to gain information about students' knowledge of collocation. The test used is lexical collocational test. It consisted of ten questions in form of multiple choices. The test included only 1 type of collocation, adverb-adjective. The researcher chose this type of collocation given to nursing department students of STIKes Widya Cipta Husada of Kepanjen to find out whether adverbadjective was also the difficult type of collocation according to Ganji's research 
in Iranian English learners. The ten questions in adverb-adjectives collocational test were gradable adjective, e.g. extremely good, and ungradable adjective, e.g. absolutely fantastic. The students had to read the questions and chose the best correct adverb or adjective.

\section{Result and Discussion}

One of the aims in this study is to investigate the knowledge of lexical collocation particularly adverb-adjective collocation among Nursing department students. There are 25 participants in this study. The descriptive statistics of the performances of students on the 10-item multiple choice test of adverb-adjective collocation are summarized in Figure 1 below. The data obtained from the students' motivation, collocation knowledge and collocation teaching, and collocational test is processed with SPSS version 16. The results are discussed below.

From the Figure below it is known that most students in Nursing Department are weak in adverb-adjective type of collocation. Researcher divides group into two groups, they are: high score group and low score group. The score is between $0-10$. The highest score is 10 and the lowest score is 0 . From the Figure 1 show that 19 students are low achiever and only 6 students are high achievers. Only one student get score 9 and two students get score 0 . The result shows that adverb-adjective is also the difficult type of collocation.

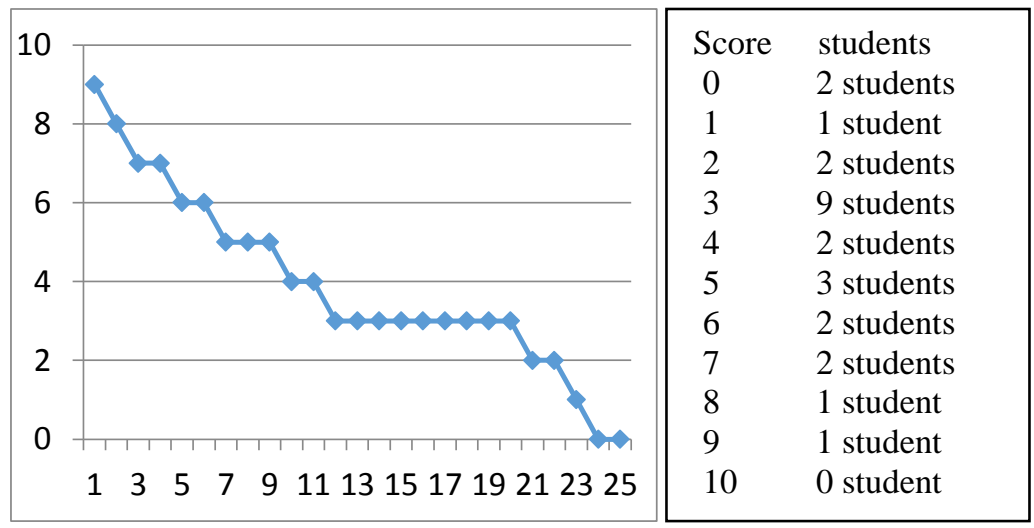

Figure 1. Students' adverb-adjective collocational type test score

The next research question is about what types of motivation influences students eager to learn English. From the result below shows that instrumental motivation plays a more important role than integrative motivation. $72 \%$ students agree that learning English helps students to think and behave like the native speakers. $60 \%$ students agree that students learn English to understand English novels and story books and

\begin{tabular}{|l|l|r|r|r|r|r|r|r|r|}
\hline \multicolumn{2}{|c|}{} & \multicolumn{2}{c|}{ Var 5 } & \multicolumn{2}{c|}{ Var 6 } & \multicolumn{2}{c|}{ Var 7 } & \multicolumn{2}{c|}{ Var 8 } \\
\hline & & Frequency & Percent & Frequency & Percent & Frequency & Percent & Frequency & Percent \\
\hline Valid & 1 & 2 & 8.0 & 6 & 24.0 & 0 & 0 & 1 & 4.0 \\
\hline
\end{tabular}




\begin{tabular}{|l|l|r|r|r|r|r|r|r|r|}
\hline & 2 & 18 & 72.0 & 15 & 60.0 & 21 & 84.0 & 15 & 60.0 \\
\cline { 2 - 10 } & 3 & 4 & 16.0 & 2 & 8.0 & 3 & 12.0 & 7 & 28.0 \\
\cline { 2 - 10 } & 4 & 1 & 4.0 & 1 & 4.0 & 0 & 0 & 2 & 8.0 \\
\cline { 2 - 9 } & 5 & 0 & 0 & 1 & 4.0 & 1 & 4.0 & 0 & 0 \\
\hline & & 25 & 100 & 25 & 100.0 & 25 & 100.0 & 25 & 100.0 \\
\hline Means & 2.16 & & 2.04 & & 2.24 & 2.40 & \\
\hline $\begin{array}{l}\text { Overall } \\
\text { Means }\end{array}$ & \multicolumn{10}{|c|}{2.21} & & & & \\
\hline
\end{tabular}

Table 1. Instrumental Motivation

\begin{tabular}{|c|c|c|c|c|c|c|c|c|c|}
\hline & & \multicolumn{2}{|c|}{ Var 1} & \multicolumn{2}{|c|}{ Var 2} & \multicolumn{2}{|c|}{ Var 3} & \multicolumn{2}{|c|}{ Var 4} \\
\hline & & Frequency & Percent & Frequency & Percent & Frequency & Percent & Frequency & Percent \\
\hline \multirow[t]{6}{*}{ Valid } & 1 & 9 & 36.0 & 22 & 88.0 & 15 & 60.0 & 11 & 44.0 \\
\hline & 2 & 8 & 32.0 & 3 & 12.0 & 9 & 36.0 & 11 & 44.0 \\
\hline & 3 & 2 & 8.0 & 0 & 0 & 1 & 4.0 & 3 & 12.0 \\
\hline & 4 & 3 & 12.0 & 0 & 0 & 0 & 0 & 0 & 0 \\
\hline & 5 & 3 & 12.0 & 0 & 0 & 0 & 0 & 0 & 0 \\
\hline & Total & 25 & 100.0 & 25 & 100 & 25 & 100 & 25 & 100 \\
\hline \multicolumn{2}{|l|}{ Means } & \multicolumn{2}{|c|}{2.32} & \multicolumn{2}{|c|}{1.12} & \multicolumn{2}{|c|}{1.44} & \multicolumn{2}{|c|}{1.68} \\
\hline \multicolumn{2}{|c|}{ Overall Means } & \multicolumn{8}{|c|}{1.64} \\
\hline
\end{tabular}

Table 2. Integrative Motivation

The third research question is about whether students' English teacher have taught collocation in the teaching and learning process. Tables below show students' opinion about collocation and collocation teaching they had gotten before entering university. In Table 3, $60 \%$ students state that they are slight in understanding and recognizing what collocation is. In Table 4, $84 \%$ students state that they do not know well the importance of collocation in English. In Table 5, 56\% students state that their English teachers teach collocation implicitly. In Table 6, 60\% students state that their English teachers teach collocation explicitly. From the results show that English teachers have taught collocation both implicitly and explicitly. However, most of students are still weak in collocation. This results reject Ganji's result that teachers did not pay attention in teaching collocation.

\begin{tabular}{|ll|r|r|}
\hline & Frequency & Percent \\
\hline Valid & 1 & 7 & 28.0 \\
& 2 & 15 & 60.0 \\
& 3 & 3 & 12.0 \\
& Total & 25 & 100.0 \\
\hline
\end{tabular}

Table 3. Students' opinion about collocation Note $: 1=$ Yes

$$
\begin{aligned}
& 2=\text { Rarely } \\
& 3=\text { No }
\end{aligned}
$$

\begin{tabular}{|ll|r|r|}
\hline & Frequency & Percent \\
\hline Valid & 1 & 3 & 12.0 \\
& 2 & 21 & 84.0 \\
& 1 & 4.0 \\
& Total & 25 & 100.0 \\
\hline
\end{tabular}

Table 4. Studentss' awareness of collocation

\begin{tabular}{|ll|r|r|}
\hline & Frequency & Percent \\
\hline Valid & 1 & 14 & 56.0 \\
& 2 & 6 & 24.0 \\
3 & 5 & 20.0 \\
& Total & 25 & 100.0 \\
\hline
\end{tabular}

Table 5. Students' opinion about their teacher's collocation teaching implicitly 


\begin{tabular}{|ll|r|r|}
\hline & & \\
& & Frequency & Percent \\
\hline Valid & 1 & 15 & 60.0 \\
& 2 & 8 & 32.0 \\
& 3 & 2 & 8.0 \\
& Total & 25 & 100.0 \\
\hline
\end{tabular}

Table 6. Students' opinion about their teacher's collocation teaching explicitly

The last research question is whether students do much exposure in using collocation. In Table 7 below, $76 \%$ students affirm that collocation is difficult. And in Table 8 below, 56\% students state that they are little in practicing English (particularly collocation) to communicate with peers, teacher and others.

\begin{tabular}{|ll|r|r|}
\hline & Frequency & Percent \\
\hline Valid & 2 & 19 & 76.0 \\
& 3 & 6 & 24.0 \\
& Total & 25 & 100.0 \\
\hline
\end{tabular}

Table 7. Students' view of the difficulty of collocation

\begin{tabular}{|ll|r|r|}
\hline & Frequency & Percent \\
\hline Valid & 1 & 3 & 12.0 \\
& 2 & 14 & 56.0 \\
3 & 8 & 32.0 \\
& Total & 25 & 100.0 \\
\hline
\end{tabular}

Table 8. Students' collocation exposure

Table 9 below represents students' motivation. There are 12 questions to gain the data whether they have high motivation or low motivation in learning English. The overall means score is 1.85 . it means that most of the students are rare to learn English by themselves, are rare to ask to the teachers if they face difficulty in learning English, and rare to spend their spare time to increase their English ability. It means that they have low motivation in learning English and do not do much exposure in using collocation.

Statistics

\begin{tabular}{|l|r|r|r|r|r|r|r|r|r|r|r|r|}
\hline & Var & & & & & & Var_ & Var_ \\
12
\end{tabular}

Table 9. questionnaire of motivation 2

\section{Conclusion}

This paper has discussed Ganji's concern about the weak scores of Iranian EFL learners' Collocational Competence caused by of Gender and Years of Instruction. Gender is one of learner differences which can affect students' short term memory to comprehend the role and the use of collocation. However, it is too early to judge that the years of instruction also affect students' failure in applying collocation. There are many factors should be considered to be the acceptable and valid reason of students' failure in using collocation such as motivation, such as personality, intelligence, aptitude, learner's belief and learning styles.

The most important in collocational input is the modify input from the knowledgeable teachers. Teachers must emphasize the role of modification of interaction in using collocation. Teachers must have capability and proficiency to do comprehension check with students 
so the students will not make errors or mistakes in using collocation.

The important thing should be concerned that for EFL learners, language environment is a factor in giving influence whether EFL learners are successful in acquiring foreign language or not. Language environment can affect language learners. Subconscious acquisition of a language will make students more successful than conscious acquisition. It means that natural exposures have big impact on students' skill in the target language (Dulay, 1982). Formal instruction is also needed to enhance students' achievement in using collocation both in writing or speaking and two other skills, listening and reading.

The error is using collocation can be caused by many factors such as learner differences or language learners. It s not appropriate to blame teachers should be responsible in students' failure in using collocation. Teachers are mediators or facilitators who give modified input and via classroom interaction will produce output to students' skills and competence. Then, learners' differences and environment, which affect to language learners, will carry input to be long memory term or short memory term.

Eventually, this study is lack of perfectness. It is needed to conduct further research in investigating the collocation's error made by non-native English learners since there many factors contribute collocation's error. Hopefully this research also can help teachers to provide activities and media in teaching collocation due to the importance of collocation in English.

If the students are failed in applying collocation, it needs further research whether other factor have role in collocation'errors by students. This study gives evidence that the lack of exposure will influence students' collocational competence.

\section{References}

Alsayed, M. (2003). Factors that contribute to Success in Learning English as Foreign Language. Damascus University Journal, 19, 21-44.

Djamarah, S. B. (2002). Psikologi belajar. Jakarta: PT Rineka Cipta.

Dornyei, Z. (2001). Motivational Strategies in the Language Classroom. Cambridge: Cambridge University Press.

Dulay, H., Burt, M., \& Krashen, S. (1982). Langauge Two. New York: Oxford University Press.

Ellis, R. (1997). Second Language Acquisition. New York: Oxford University Press.

Emaliana, I. (2012). A Survey on the Realtionship between Motivation and Achievement of. Malang: Universitas Negeri Malang.

Ganji, M. (2012). On the Effect of Gender and Years of Instruction on Iranian EFL Learners' Collocational Competence. A Descriptive in Nature in Iran. CSS Journal., 5, 123-133.

Gardner, R. C., \& Lambert, W. E. (1972). Attitudes and Motivation in Second Language Learning. Massachusetts: Newbury House Publishers.

Lightbown, M. P., \& Spada, N. (2001). How Language are learned (2 ed.). New York: Oxford University Press.

Prendergast, T. (1864). The Mastery of languages: Or, The Art of Speaking Foreign Tongues Idiomatically. London: Richard Bentley.

Saville, M., \& Troike. (2006). Introducing Second Language 
Acquisition. New York:

Cambridge University Press.

Slameto. (1995). Belajar dan Faktor-

faktor yang Mempengaruhinya.

Jakata: PT Rineka Cipta.

William, M., \& Burden, R. L. (1997).

Psycholog for Language

Teacher: A Social Constructivist

Approach. Cambridge:

Cambridge University Press. 